\title{
Security, Reliance and Availability: Psychometric features of the Kerns' Security Scale in Hungarian population
}

\author{
BEATRIX BARCSI ${ }^{1}$ - KATALIN HOLLÓDY² - \\ BERNADETTE PÉLEY ${ }^{3}$ - KRISZTINA DORN² - KATHRYN A. KERNS ${ }^{4}$ \\ - SÁNDOR RÓZSA ${ }^{5}$ - IMRE A. TÖRÖK ${ }^{6}$ - JÁNOS KÁLLAI ${ }^{*}$ \\ ${ }^{1}$ Department of Otorhinolaryngology, Clinical Centre, University of Pécs, Pécs, Hungary \\ ${ }^{2}$ Department of Pediatrics, Clinical Center, University of Pécs, Pécs, Hungary \\ ${ }^{3}$ Department of Developmental and Clinical Psychology, Faculty of Humanities, \\ University of Pécs, Pécs, Hungary \\ ${ }^{4}$ Department of Psychology, Kent State University, Kent, USA \\ ${ }^{5}$ Department of Psychiatry, School of Medicine, Washington University, St. Louis, USA \\ ${ }^{6}$ Department of Applied Psychology, Semmelweis University, Budapest, Hungary \\ ${ }^{7}$ Institute of Behavioral Sciences, Medical School, University of Pécs, Pécs, Hungary
}

(Received: 9 September 2016, accepted: 16 March 2017)

Background: This study examines the Kerns' Security Scale (KSS) that is a self-report questionnaire to assess school-age children's certain family-related experiences, and is widely used in the United States and in certain European countries. Objectives: The aim of the present investigation is to review the factor structure of the KSS in Hungarian population and to describe the characteristics of the scales in an Eastern-Central European country, as well as to check its external validity by the Child Depression Inventory, and to evaluate its feasibility in clinical practice and school psychology services. Methods: The sample consisted of 323 primary and secondary schools students (137 boys and 186 girls), aged 10-18 years. They completed the Kerns' Security Scale and the Child Depression Inventory. Results: statistical analysis has revealed that the items of the security questionnaire can be divided into three subscales, namely: Reliance, Availability, and Autonomy support. The mothers' subscale scores are higher than fathers' subscale scores (Reliance: $t=7.1, p<.001$; Availability $t=8.9, p<.001$; Autonomy support $t=3.2$, $p<.01)$. Conclusion: The results supported the three factor model of the KSS, and recommended to apply for clinical practice and in school psychology services.

Keywords: attachment, autonomy support, depression, preadolescence, perceived security

\footnotetext{
* Corresponding author: Dr. János Kállai, University of Pécs, Medical School, Institute of Behavioral Sciences, H-7624 Pécs, Hungary, Szigeti út 12. E-mail: janos.kallai@aok.pte.hu
} 


\section{Introduction}

In recent years there has been growing interest in the study of attachment in middle childhood. The quality of the attachment relationship influences a number of aspects of childhood development, such as basic feelings of security, capacity for affect regulation, self-esteem, interpersonal skills, the ability to explore the world freely, as well as the quality of later parenting (Carlson \& Sroufe, 1995). In secure attachment, children hold beliefs based on previous experience concerning the availability of the parents and reliance upon parents (Brumariu \& Kerns, 2010). There is limited number of assessment methods available for measuring attachment security in the relationship of caregivers and children in mid- and late childhood, and the reliability of their factor structure is debated (Dwyer, 2005). In clinical practice, projective techniques, e.g. the modified Doll Story Completion Task (Granot \& Mayseless, 2001), and semi-projective interview procedures (Target et al., 2003) are used as therapists need to evaluate the deeper structure of children's security and its developmental history. However, the screening of security-related disorders requires the application of reliable questionnaires in larger mid-childhood populations.

One of the most prominent self-report measurement tools of attachment behavior is the Kerns' Security Scale (KSS; Kerns, Aspelmeier, Gentzler, \& Grabill, 2001) that contains one main factor. In a study by Lieberman et al. (1999) this security factor was divided into two subscales, labeled as Availability and Dependence, but in psychology praxis generally the onefactor model is used. To avoid the associations with traits, Kerns et al. (2006) suggested renaming the Dependence subscale to Reliance (on the attachment figure). The KSS can be used to assess perceived attachment security both across childhood and adolescence (van Ryzin \& Leve, 2012). Children who experience that their father and mother provide security are significantly more accepted by peers, have more reciprocated friendships, and are more responsive and less critical with their close friends (Kerns, 2008). When in middle childhood children gradually leave the dependent position in the family, they carry with them the represented security feelings and the notion that they are respected and loved, while they are afield, consequently they can receive help if they lay claim of it (Lieberman et al., 1999).

A large number of studies tested the validity and reliability of the KSS in different cultures, age groups, and under stress conditions, both clinical and community settings (Granot \& Mayseless, 2001; Kern 2008; Sümer \& Anafarta Şenda ğ, 2009; Verschueren \& Marcoen, 2002). The internal consistency of the KSS is high for both mothers and fathers, with Cronbach's alpha coefficient ranging from .64 to .93 (Al-Yagon, 2011; Granot \& Mayseless, 2001; Guttmann-Steinmettz et al., 2011; Lieberman, Doyle \& 
Markiewicz, 1999). Test-retest reliability was found to be 75 (Brumariu \& Kerns, 2010), but the stability of subscales' structure depends on the tested age-groups and cultures (Kerns et al., 2006; Richaud de Minzi, 2006). Since detailed factor structure analysis has not yet been conducted to improve the application potential of the KSS, it is necessary to reexamine the structure of the measure across different ages and cultures on larger samples.

The Kerns' Security Scale has been translated to Dutch by Verschueren and Marcon (2002). They explicitly tested the one-factor model of the KSS, and found acceptable reliability scores for mothers and fathers. Later, the KSS has been translated to Spanish (Richaud de Minzi, 2006), Turkish (Sümer \& Anafarta Şendağ, 2009), Hebrew (Granot \& Mayseless, 2001) and Serbian (Langher, Kourkoutas, Scurci, \& Tolve 2010) languages. Previous research has demonstrated good psychometric proprieties of the KSS. It has good internal consistency and test-retest reliability, and the security scores correlate with mothers' behavior and children's social and emotional adjustment (Kerns, Schlegelmich, Morgan, \& Abraham, 2005).

The aim of this study is to check the psychometric features of the KSS in a Hungarian mid- and late childhood sample. As attachment security associates with depression (Goodman et al., 2011), children's depression values were tested, and they are used as external validity scores for the Kerns' Security Scales.

\section{Method}

\subsection{Participants}

Children were recruited from a large population of primary and secondary schools in Hungary. The children have a permission from their parents to participate in the examination. The data gathering was anonymous, the children have not received any reward for their activity. All participants have no perceptual deficiency and school performance below average. Altogether 418 children were invited in the study but 323 of them completed each required questionnaire. The children's age range was between 10-18 years, including 137 boys (mean ages: 14.3 years, SD $=2.2$ years) and 186 girls (mean ages: 13.9 years, $\mathrm{SD}=2.1$ years). Both the children and their parents were informed on the process of the study and declared their active participation in questionnaire completion. The study was conducted according to the principles of the Declaration of Helsinki and approved by the Regional Research Ethics Committee of the University of Pécs Medical School (permission number: 4598). 


\subsection{Procedure}

As part of a larger project, the children were asked to complete a package of questionnaires involving the Kern's Security Scale (KSS) in relation to their mother and father, and the Child Depression Inventory (CDI).

\subsection{Measures}

The Kerns's Security Scale (Kerns et al., 2001) is a self-report measure consisting of 15 items for the mother, and 15 items for the father that assess children's perceptions of a particular attachment relationship. In the current study, we aimed to assess children's perceptions of their attachment with their mother, and father, and the family's global security potential. The items were administered using Harter's format, in which children are presented information about two types of kids, and are asked to decide which one is most like them, and then to indicate whether they are "really like" or "sort of like" that type of kid. The questionnaire includes items such as "some kids find it easier to trust their mom, but other kids are not sure if they can trust their mom." Each item is scored from 1 to 4 , from left to right, with a higher score representing greater security for mother and father, respectively. The original English version of the KSS contains two factors: Reliance (items: 1, 2, 3, 5, 6, 9, 12, 13, 15) and Availability (items: 4, 7, 8, 10, 11, 14). Items $1,3,4,9,10,13,15$ should be scored conversely. The global family security score was defined by summing the scores of mother and father security values. The scale provides scores on a single, continuous dimension of security, based on the average of the item scores, with the average score ranging from 1-4. The text of the KSS was translated to Hungarian language by an expert psychologist, then retranslated to English. The final version of the items was supervised by Kathryn A. Kerns. (The Hungarian version of the KSS is attached in Appendix 1)

The Child Depression Inventory (CDI; Kovacs, 1985; Hungarian adaptation: Rózsa et al., 1999) is a 27-item, extensively applied clinical measure for the assessment of depressive symptoms of children and adolescents. The items cover an array of symptoms of childhood depression such as sadness, anhedonia, suicidal ideation, as well as sleep- and appetite disturbances. Each item refers to one symptom by presenting three choices, graded from 0 to 2 in the direction of increasing depression. The CDI total scores range from 0 to 54, 20 indicating clinical depression. The CDI Negative Mood, Ineffectiveness, Anhedonia and Interpersonal problem scales had good internal consistency values slightly above .60, except for Interpersonal Problems scale which shows poor internal consistency (.36) (Ivarsson, Svalander, \& Litlere 2009). In Hungarian sample the Cronbach's alpha for 
the CDI total score was .75 (Kriston, Pikó, \& Kovács, 2012). In the present sample the Negative mood subscale (mean $=7.05, \mathrm{SD}=7.50$, Cronbach's alpha $=.94)$; Ineffectiveness subscale (mean $=2.12, \mathrm{SD}=1.67$, Cronbach's alpha $=.73)$; and Anhedonia subscale $($ mean $=1.59, \mathrm{SD}=1.7$, Cronbach's alpha $=.72)$ of the CDI were acceptable expecting the Interpersonal problems subscale (mean $=1.87, \mathrm{SD}=2.14$, Cronbach's alpha $=.60$ ) wherein the internal consistency score was relatively low.

\subsection{Data Analysis}

Throughout this study, the Kerns' Security Scale for mother and father was analyzed separately. The factor structure was analyzed through a Principal Component Analysis (PCA) with Varimax rotation. Maximum likelihood confirmatory factor analyses (CFA) were conducted over the covariance matrices of the Kerns' Security Scale to test the hypothesized factor structures. The analyses were performed through the AMOS 7 statistical package (Arbuckle, 2006). The following goodness-of-fit indices were used to assess the degree of fit between the proposed model and the sample data: (a) the $\chi^{2}$ statistic; (b) the comparative fit index (CFI); (c) the Tucker-Lewis nonnormed fit index (TLI); (d) the root mean square error of approximation (RMSEA); (e) the Akaike information criterion (AIC). A non-significant $p$ value of $\chi^{2}$ corresponds to an acceptable fit, or $\chi^{2}$ divided by degrees of freedom should be two or lower. Given our relatively large sample, we did not rely on the formal chi-square test to evaluate model fit only, as it is known to produce excessive Type I error rates in large samples, while it is also unusual to obtain non-significant $\chi^{2}$ values when performing CFAs on self-reported questionnaires (Marsh et al., 1988). CFI and TLI values greater than .95 suggest an acceptable fit (Hu \& Bentler, 1999; Tabachnick \& Fidell 2007). The Tucker-Lewis nonnormed fit index (Tucker \& Lewis, 1973) measures the improved fit in a manner similar to the CFI, with an adjustment for the degrees of freedom in the model. For the RMSEA, a cutoff value ranging from .05 or lower indicates a good model fit and values up to .08 represent a moderate model fit (Schermelleh-Engel et al., 2003). The Akaike information criterion (Akaike, 1974) is also included. When two models are compared on this statistics, smaller values suggest a better fit.

Means, standard deviations, and Cronbach's alpha coefficients were calculated for each of the scales. The mother' and father' KSS factor scores were compared by paired sample $t$-test. Pearson's correlation was used to test the convergence between the Kerns' Security Scale and the Child Depression Inventory. In addition, basic statistical analyses were carried out with version 19.0 of the SPSS statistical software, in which significance was assumed with $p<.05$. 


\section{Results}

\subsection{Factor analysis of the Kerns' Security Scale}

\subsubsection{Exploratory Factor Analysis (EFA)}

Separate principal component analyses (PCA) were performed for mother and father items. Three factors were extracted from mother items with the condition of eigenvalues greater than 1, which accounted for $59.41 \%$ of the variance. The eigenvalues for the three factors were 4.79, 2.66, and 1.45, respectively. Similarly, three factors were extracted from father items, which accounted for $63.97 \%$ of the variance. The eigenvalues for the three factors were 6.72, 1.80, and 1.07, respectively. The standardized factor loadings following Varimax rotation in a three-factor solution are presented in Table 1. All 15 items have similar factor loadings of mother and father evaluation, but item 6. autonomy, 12. personal respect, and 15. parent comforting have cross-loaded highly on two factors. Seven of 15 items allocated to the Reliance factor (1. trust, 3. easy to count, 4. enough time, 9. understanding, 10. sureness, 13 . proximity seeking, 15. parent comforting). Four items (7. emotionally close, 8. feel loved, 11. parent availability, 14. parent helps) allocated to the Availability factor in mother evaluation, and 6 items (6. autonomy, 7. emotional close, 8 . feel loved, 11. parent availability, 12. personal respect, 14. parent helps) in father evaluation. The third factor, labeled Autonomy support, consisted of 4 items (2. autonomy support, 5 . share thoughts, 6 . autonomy, 12 . personal respect) in mother evaluation and 2 items (2. autonomy support, and 5. share thoughts) in father evaluation.

\subsubsection{Confirmatory Factor Analysis (CFA)}

Initially, a one-factor CFA model was tested for mother and father items. In this model, all parcels loaded on a single latent factor. All of the error terms were uncorrelated. This model showed poor global fit (Table 2). Subsequently, Lieberman et al. (1999) two-factor model was suggested. In this model the 15 items loaded on two factors that were identified as Reliance and Availability. Although this model manifested better fit than the onefactor model, overall it showed poor global model fit for mother and father items. The analysis of Model 3 has resulted significantly better fit compared to Model 2. The statistics for fit improvement between Model 2 and Model 3 are shown in Table 2. The general factor represents the overarching 
construct, and each group factor represents one of the sub-constructs. The general factor influences all indicators. Each group factor influences only the indicators for a sub-construct. The bi-factor analysis is a form of confirmatory factor analysis originally introduced by Holzinger and Swinefold (1973). The bi-factor model has a general factor and a number of group factors. This bi-factor model showed an acceptable global fit between the proposed model and the data, where $\chi^{2}=262.64, p<.001, \chi^{2} / \mathrm{df}=3.502$, $\mathrm{CFI}=.936, \mathrm{TLI}=.910, \mathrm{RMSEA}=.077$. Moreover, modification indices revealed significant error covariation between the following item pairs: item 6 and 13, item 6 and 15, item 12 and 14.

Table 1. Results of principal component analysis of the Kerns`Security Scale

\begin{tabular}{|l|l|l|l|l|l|l|}
\hline & \multicolumn{3}{|c|}{ Mother } & \multicolumn{3}{c|}{ Father } \\
\hline & \multicolumn{1}{|c|}{ I. } & \multicolumn{1}{|c|}{ II. } & \multicolumn{1}{c|}{ III. } & \multicolumn{1}{|c|}{ I. } & II. & III. \\
\hline Trust & .91 & & & .86 & & \\
\hline Autonomy support & & & .55 & & & .84 \\
\hline Easy to count & .91 & & & .87 & & \\
\hline Enough time & .63 & & & .59 & & \\
\hline Share thoughts & & & .64 & & & .64 \\
\hline Autonomy & & & .80 & & .58 & .51 \\
\hline Emotionally close & & .70 & & & .71 & \\
\hline Feel loved & & .75 & & & .62 & \\
\hline Understanding & .74 & & & .73 & & \\
\hline Sureness & .88 & & & .89 & & \\
\hline Parent availability & & .63 & & & .74 & \\
\hline Personal respect & & .51 & .55 & & .52 & .50 \\
\hline Proximity seeking & .71 & & & .57 & & \\
\hline Parent helps & & .66 & & & .76 & \\
\hline Parent comforting & .62 & & .45 & .65 & & \\
\hline $\begin{array}{l}\text { Explained variance } \\
\text { (\%) }\end{array}$ & 28.76 & 16.15 & 14.50 & 29.24 & 22.62 & 12.11 \\
\hline
\end{tabular}

Note: Varimax rotation including factors with eigenvalues $>1$ ) Loadings with absolute values of .40 or less are omitted. 


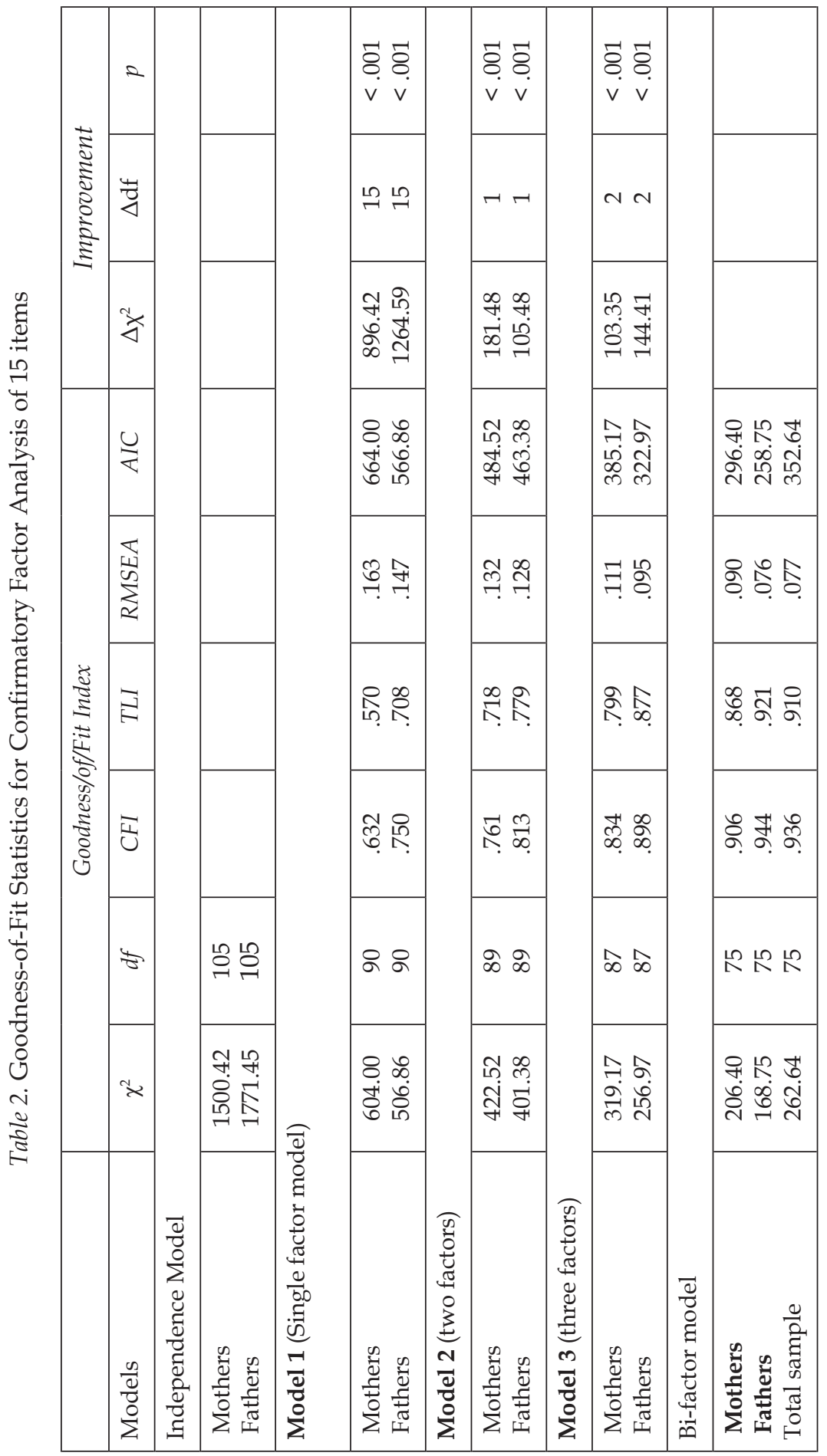


Each item of the Kerns' Security Scale was constrained to load simultaneously on the general factor and on the domain-specific dimension. Figure 1 presents the item loadings on both the general factor and the domain-specific dimensions. All of the Reliance items loaded moderately $(\geq$ .40) on their factor. As for the Availability items, 2 items $(7,14)$ of 4 loaded moderately on the Availability factor. Finally, as for the Autonomy support items, only 1 (item 5) of the 4 items loaded moderately on the Autonomy support factor. Overall, 10 of the 15 items loaded moderately on their designated specific dimensions. All items of the Kerns' Security Scale items were moderately associated with the general security dimension except for item 2.

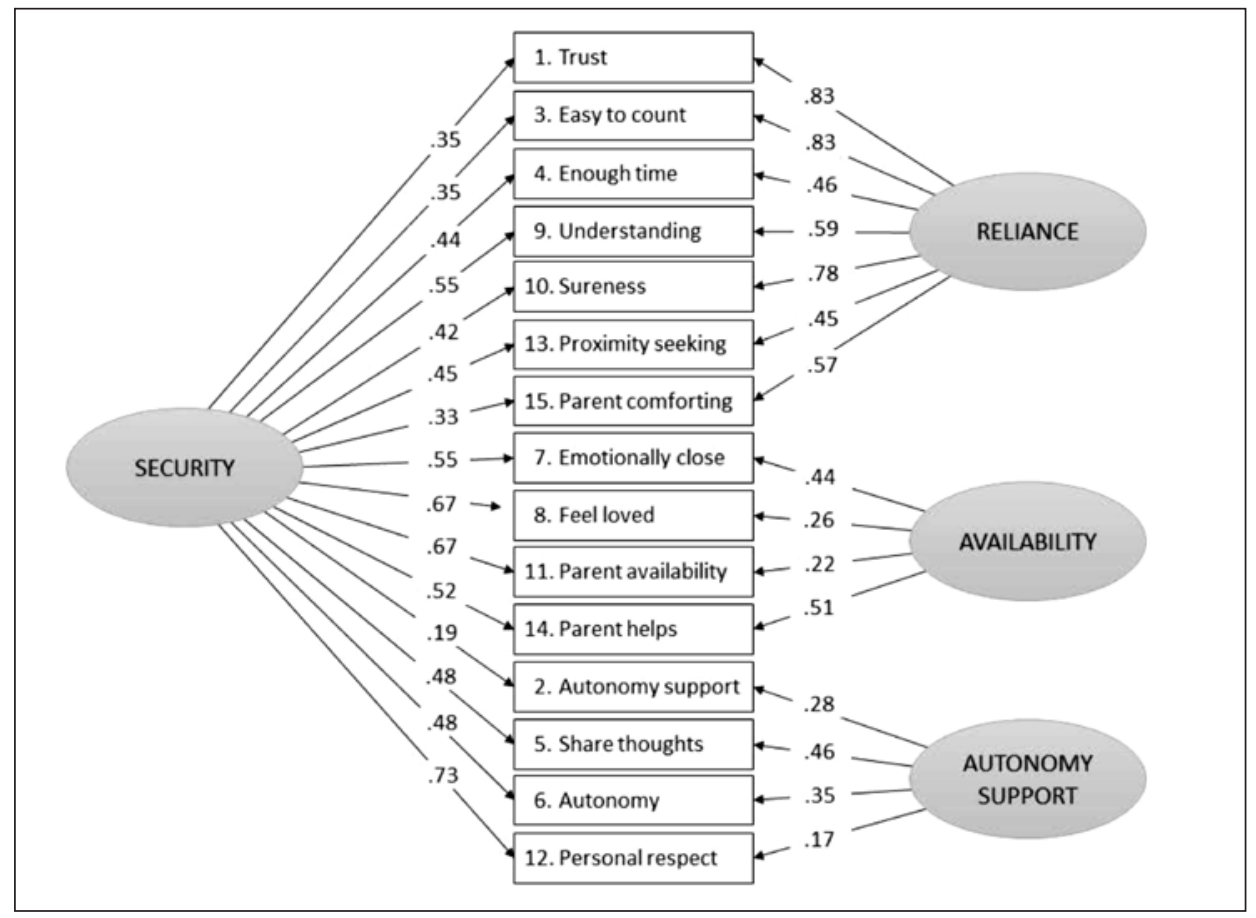

Figure 1. Three-factor model of Kerns' Security Scale containing reliance, availability, and autonomy support factors

\subsection{Descriptive statistics and internal consistency}

The mean scores and standard deviations and Cronbach's alpha coefficients for the Kerns' Security scales and subscales along with gender differences are shown in Table 3. The Cronbach's alpha coefficients varied from .65 
(Autonomy support) to .91 (Reliance) for the mother's evaluation, and from .66 (Autonomy support) to .90 (Reliance) for the father evaluation based on the total sample, which demonstrates mostly an acceptable internal consistency. Lower alpha value can only be found in the Autonomy support scale. Comparing the perceived security capacity of the mother and the father, mothers' scores were higher in Reliance, Availability and Autonomy support, and the total security scores on the KSS (Table 3).

Table 3. Internal consistency reliabilities (Cronbach's a), means, standard deviations (SD), and differences evaluation for mother and father on the Kerns' Security Scale and subscales

\begin{tabular}{|c|c|c|c|c|c|c|c|c|}
\hline \multirow{2}{*}{$\begin{array}{c}\text { Kerns' } \\
\text { Security } \\
\text { Scale and } \\
\text { subscales }\end{array}$} & \multirow{2}{*}{$\begin{array}{l}\text { Number } \\
\text { of item }\end{array}$} & \multicolumn{2}{|c|}{ Cronbach's a } & \multicolumn{2}{|c|}{ Mother } & \multicolumn{2}{|c|}{ Father } & \multirow{2}{*}{$\begin{array}{c}t \\
p<\end{array}$} \\
\hline & & Mother & Father & Mean & SD & Mean & SD & \\
\hline Reliance & 7 & .91 & .90 & 3.36 & .83 & 3.07 & .85 & $\begin{array}{r}7.1 \\
.001\end{array}$ \\
\hline Availability & 4 & .72 & .80 & 2.15 & .61 & 1.84 & .84 & $\begin{array}{r}8.9 \\
.001\end{array}$ \\
\hline Autonomy & 4 & .65 & .66 & 1.70 & .73 & 1.86 & .76 & $\begin{array}{l}3.2 \\
.01\end{array}$ \\
\hline Security Scale & 15 & .84 & .89 & 3.31 & .55 & 3.03 & .68 & $\begin{array}{r}5.8 \\
.001\end{array}$ \\
\hline
\end{tabular}

3.3. External validity of the Kerns' Security Scale and the CDI subscales

The correlation between KSS security and the CDI scores were analysed, and we found that security and depression total sores and factors correlations varies between -.23 and -.68 in both mothers' and fathers' evaluations. The results (see Table 4) indicate that lower security associates with higher depression values.

\subsection{Age in association with factors scores}

Considering the rapid cognitive and emotional changes in the school age population, we evaluated associations between age and factor scores. Correlation analyses revealed a negative weak association between age and the total security score for mother $(r=-.27, p<.001)$, for father $(r=-.27, p<$ .001). Similar association was found in the case of Reliance for mother $(r=$ 
$-.31, p<.001)$ and for father $(r=-.28, p<.001)$. Certain age effect can be detected in the Availability and Autonomy support factors, but only for fathers (Availability $r=-.15, p=.046$ and Autonomy support $r=-.17, p=.014$ ). For mothers, the association of age with Availability and Autonomy support factors cannot be detected (Availability $r=-.06, p=.714$, Autonomy support $r=-.09, p=.285)$.

Table 4. The Kerns' Security Scale and subscales correlations with the Child Depression Inventory (CDI)

\begin{tabular}{|l|c|c|c|c|}
\hline \multirow{2}{*}{} & \multicolumn{4}{|c|}{$\begin{array}{c}\text { Mother } \\
\text { Father }\end{array}$} \\
\cline { 2 - 5 } & Reliance & Availability & Autonomy & Security \\
\hline Negative mood & $-.66^{* *}$ & $-.20^{* *}$ & $-.16^{* *}$ & $-.58^{* *}$ \\
& $-.53^{* *}$ & $-.26^{* *}$ & $-.15^{* *}$ & $-.44^{* *}$ \\
\hline Interpersonal & $-.46^{* *}$ & $-.17^{* *}$ & $-.24^{* *}$ & $-.46^{* *}$ \\
problems & $-.42^{* *}$ & $-.25^{* *}$ & $-.22^{* *}$ & $-.39^{* *}$ \\
\hline Ineffectiveness & $-.35^{* *}$ & $-.21^{* *}$ & $-.26^{* *}$ & $-.40^{* *}$ \\
\hline Anhedonia & $-.37^{* *}$ & $-.33^{* *}$ & $-.31^{* *}$ & $-.42^{* *}$ \\
\hline CDI Total & $-.64^{* *}$ & $-.18^{* *}$ & $-.15^{* *}$ & $-.56^{* *}$ \\
& $-.52^{* *}$ & $-.27^{* *}$ & $-.18^{* *}$ & $-.44^{* *}$ \\
\hline
\end{tabular}

Note: $p<.01^{* *}$.

\section{Discussion}

Our data from the Hungarian sample has confirmed the basic assumption that the Kerns' Security Scale is a reliable test to assess children's parentrelated perceived security. However, statistical analysis has revealed that the reliable main dimension can be divided into three subscales, namely: Reliance, Availability, and Autonomy support. Besides the two, formerly identified factors (Reliance and Availability) in our research a third, new factor was detected, which contains items 2, 5, 6 and 12. Items of the third factor address children's perceived acceptance of their autonomy intentions. Consequently, we suggest label the new factor as Autonomy support. Considering cultural diversity and the age differences in the demand of autonomy, the assessment potential of the third factor must be established through further examinations. Since the publications of the KSS in different languages no validity examination has been carried out, so the label and the interpretation of the affected items are hypothetical. Item 2: "Some kids feel 
like their mom/dad butts in a lot when they are trying to do things, but other kids feel like their mom/dad lets them think on their own." In our view, this statement only partially refers to the dependent position of the children, as they seem to intend to behave as autonomous persons, and expect personal respect from their parents indicating that they require independent roles in the family system. Item 5: "Some kids do not really like telling their mom/dad what they are thinking or feeling, but other kids like telling their mom/dad/ what they are thinking or feeling". This sentence refers to a dyadic discourse, when two equal persons share their feelings, and children are considered as autonomous partners in this conversation. Item 6: "Some kids do not really need their mom/dad for much, but other kids need their mom/dad for a lot of things." Our interpretation the statement highlights the fact that parents can be treated as instruments, and are considered as one option, when children look for protection. Explaining the latent content of these statements, the third scale's items' statements symbolize a developmental action, as children intend to establish a certain autonomy from the family.

During factor analysis only one item's classification was debated. Item 12 loaded almost identically in two factors. Item 12: "Some kids think that their mom/dad does not listen to them, but other kids do think their mom/dad listens to them." In the face of the statistical evidence, item 12 can be treated as a relevant score in the security scale, but the label is yet pending between the Reliance, and Autonomy support scales. In the case of item 6 the interpretation is also debated, thus the Autonomy support factor involves only two stable items, item 2 and 5, and the discriminating power between Reliance and Autonomy support factors is limited in the case of item 6 and item 12. An adapted version of the Security Scale includes more items to assess autonomy support (Kerns et al., 2015).

The identification of the KSS factors may be different in different populations and cultures. Reliance and Availability have been detected in the Canadian, Spanish, and Dutch samples (Lieberman, Doyle, \& Markiewcz 1999; Richaud de Minzi, 2006; Verschueren \& Marcoen, 2002). The present analysis has supported the reliability of the Reliance and Availability factors. The first order factor's internal consistency proved to be excellent. From the Reliance factor we isolated a third one, labeled as Autonomy support that involves feelings of self-reliance, when children are assumed as individuals by the parents and they may consider themselves as autonomous persons with personal wishes, motivations and roles, respected by the parents and admitted when seeking reunion with their own families. Considering the present results, further examination is needed on this domain.

The interpretation and factor ordering of the items, especially in the Autonomy support scale may depend on sample characteristics. As revealed in the present study, age range may affect the examination results. The 
conducted correlation analyses detected that older children perceive their parents' security providing potential lower than younger school age children. This tendency manifested in each subscale score of the KSS, except for mother scores on Availability and Autonomy support, calling the attention of future examiners of the importance of the applied age-range of the assessed population. The convergence of the present sample offers only limited chance to control the age-related specificity of the factor stability. However, it was clearly demonstrated that child depression scores associated with children's perceived security in terms of both their mother and father. This result supports earlier findings reported by Duchesne \& Ratelle (2014).

Our results underline the assumption that mothers' perceived security capacity is larger than fathers' (Kerns et al., 2015). This difference is detectable in all three factors. The correlation matrix of perceived security for mother and the father (Table 4) indicates that children tend to consider parents as a complete, unified family, and the feeling of security is shared between them. We suggest that these two factors' scores may be an indication for later self-esteem and self-regulation capacity.

In sum, the application of self-related scales in the clinical- and the community health centers is a basic requirement in the diagnostic process of children's symptomatology and in the detection of the hidden lifethreatening risks. In most countries, care-provider systems tend to opt for short and reliable scales. Considering the present results with a large agerange Hungarian sample, it can be confirmed that the KSS is a reliable and valid assessment method for evaluating children's perceived security in terms of their mother and father. The two subscales, Reliance and Availability have good enough psychometric indicators to apply them for detailed analysis of the perceived security. The third subscale the Autonomy support scale requires further analyses with smaller age-range populations. Keeping these limitations in mind we support the use of the KSS as a screening test and exploration method to explicate the latent structure of the families' security forming capacity in different cultures.

\section{References}

Akaike, H. (1974). A new look at the statistical model identification. IEEE Transactions on Automatic Control, 19(6), 716-723.

Al-Yagon (2011). Adolescents' subtypes of attachment security with fathers and mothers and self-perceptions of socioemotional adjustment. Psychology, 2(4), 291-299.

Arbuckle, J.L. (2006). Amos (Version 7.0) [Computer Program]. Chicago: SPSS

Brumariu, L.E., \& Kerns, K. A. (2010). Mother-child attachment patterns and different types of anxiety symptoms: Is there specificity of relations? Child Psychiatry and Human Development, 41(6), 663-674. 
Carlson, E., \& Sroufe, L.A. (1995). The contribution of attachment theory to developmental psychopathology. In D. Cicchetti, \& D. Cohen (Eds.), Developmental processes and psychopathology: Volume 1. Theoretical perspectives and methodological approaches (581-617). New York: Cambridge University Press

Duchesne, S., \& Ratelle, C.F. (2014). Attachment security to mothers and fathers and the developmental trajectories of depression symptoms in adolescence: Which parent for which trajectory? Journal of Youth Adolescence, 43(4), 641-654.

Dwyer, K. (2005). The meaning and measurement of attachment in middle and late childhood. Human Development, 48(3), 155-182.

Goodman, S.H., Rouse, M.H., Connell, A.M., Broth, M.R., Hall, C.M., \& Heyward, D. (2011). Maternal depression and child psychopathology: A meta-analytic review. Clinical Child and Family Psychological Review, 14(1), 1-27.

Granot, D., \& Mayseless, O. (2001). Attachment security and adjustment to school in middle childhood. International Journal of Behavioral Development, 25(6), 530-541.

Guttmann-Steinmetz, S., Shoshani, A., Farhan, K., Aliman, M., \& Hirschberger, G. (2011). Living in the crossfire: Effects of exposure to political violence on Palestinian and Israeli mothers and children. International Journal of Behavioral Development, 36(1), 71-78.

Harter, S. (1982). The perceived competence scale for children. Child Development, 53(1), 87-97.

Holzinger, K.J., \& Swineforld, S. (1937). The bi-factor method. Psychometrika, 2(1), 41-54.

Hu, L., \& Bentler, P.M., (1999). Cutoff criteria for fit indexes in covariance structure analysis: Conventional criteria versus new alternatives. Structural Equation Modelling: A Multidisciplinary Journal, 6(1), 1-55.

Ivarsson, T., Svalander, P., \& Litlere, O. (2009). The Children's Depression Inventory (CDI) as measure of depression in Swedish adolescents. A normative study. Nordic Journal of Psychiatry, 60(3), 220-226.

Kerns, K.A., (2008). Attachment in Middle Childhood, In: J. Cassidy, \& P.R. Shaver (Eds.). Handbook of attachment. Theory, research, and clinical applications (366-382). New York: Guilford Press

Kerns, K.A., Aspelmeier, J.E., Gentzler, A.L., \& Grabill, C.M. (2001). Parent-child attachment and monitoring in middle childhood. Journal of Family Therapy, 15(1), 69-81.

Kerns, K.A., Klepac, L., \& Cole, A., (1996). Peer relationships and preadolescents' perceptions of security in the child-mother relationship. Developmental Psychology, 32(3), 457-466.

Kerns, K. A., Mathews, B. L., Koehn, A. J., Williams, C. T., \& Siener-Ciesla, S. (2015). Assessing both safe haven and secure based support in parent-child relationships. Attachment and Human Development, 17(4), 337-353.

Kerns, K.A., Schlegelmich, A., Morgan, T.A., \& Abraham, M. (2005). Assessing attachment in middle childhood. In K. A. Kerns, R. A. (Eds.), Attachment and childhood (46-70). New York: Guilford Press

Kerns, K.A., Tomich, P.L., \& Kim, P. (2006). Normative trends in children's perceptions of availability and utilization of attachment figures in middle childhood. Social Development, 15(1), 1-22.

Kovacs, M. (1985). The Children's Depression Inventory (CDI). Psychopharmacology Bulletin, 21(4), 995-999.

Kriston, P., Pikó, B., \& Kovács, E. (2012). Önminősített egészségmutató, mint a pszichológiai jólét indikátora: serdülő populáció körében végzett magatartás-epidemiológiai elemzés. Orvosi Hetilap, 153(47), 1875-1882.

Langher, V., Kourkoutas, E., Scurci, G., \& Tolve, G. (2010). Perception of the security of attachment in neurologically ill children. Procedia Social and Behavioral Sciences, 5, 2290 2294. 
Lieberman, M., Doyle, A.B., \& Markiewicz, D. (1999). Developmental patterns in security of attachment to mother and father in late childhood and early adolescence: Associations with peer relations. Child Development, 70(1), 202-213.

Marsh, H.W., Balla, J.R., \& McDonald, R. P. (1988). Goodness-of-fit indexes in confirmatory factor analysis: The effect of sample size. Psychological Bulletin, 103(3), 391-410.

Richaud de Minzi, M.C. (2006). Loneliness and depression in middle and late childhood: The relationship to attachment and parental style. The Journal of Genetic Psychology, 167(2), 189-210.

Rózsa, S., Vetró, Á., V. Komlósi, A., Gádoros, J., Kő, N., \& Csorba, J. (1999). Gyermek- és serdülőkori depresszió kérdőíves mérésének lehetősége a klinikai és normatív mintán szerzett tapasztalatok alapján. (Clinical and normative sample based measurement of depression by questionnaire in childhood and adolescence.) Pszichológia, 19(4), 459-482.

Schermelleh-Engel, K., Moosbrugger, H., \& Müller, H. (2003). Evaluating the fit of structural equation models: test of significance and descriptive goodness-of-fit measures. Methods of Psychological Research Online, 8(8), 23-74.

Skrabski, Á., Kopp, M., Rózsa, S., Réthelyi, J., \& Rahe, R.H. (2005). Life meaning: An important correlate of health in the Hungarian population. International Journal of Behavioral Medicine, 12(2), 78-85.

Sümer, N., \& Anafarta Şendağ, M. (2009). Orta Çocukluk Döneminde Ebeveynlere Bağlanma, Benlik Algisıve Kayg1. Turk Psikoloji Dergisi, 24(63), 86-101.

Target, M., Fonagy, P., \& Shmueil-Goezt, Y. (2003). Attachment representations in schoolage children: The development of the Child Attachment interview (CAI). Journal of Child Psychotherapy, 29(2), 171-186.

Tabachnick, B.G., \& Fidell, L.S. (2007). Using Multivariate Statistics ( $5^{\text {th }}$ edition). New York: Altlyn and Bacon

Tucker, L.R., \& Lewis, C. (1973). A reliability coefficient for maximum likelihood factor analysis. Psychometrika, 38(1), 1-10.

Van Ryzin, M.J., \& Level, L.D. (2012). Validity evidence for the security scale as a measure of perceived attachment security in adolescence. Journal of Adolescence, 35(2), 425-431.

Verschueren, K., \& Marcoen, A. (2002). Perceptions of self and relationship with parents in aggressive and nonaggressive rejected children. Journal of School Psychology, 40(6), 501-522.

\section{Acknowledgements}

The study was supported by T-106176. OTKA Grant.

\section{Division of labor}

Barcsi, B. and Hollody, K.: study design, organization and recruitment; Török, I.: conduct of examination; Péley, B, and Dorn, K.: design, manuscript edition and introduction; Rózsa, S.: statistical analysis; Kerns, K. and Kállai, J.: theoretical background and design, text edition, control of investigation.

\section{Conflict of Interests Statement}

The authors have no conflict of interest to declare. 


\section{Appendix:}

Kerns-féle Biztonság Skála (KSS)*

Tájékoztatás: Szeretnénk feltenni Neked néhány kérdést rólad és az anyukádról, valamint rólad és az apukádról. Minden állítás két különböző gyerektípusról szól, és szeretnénk tudni, hogy a kettő közül melyikhez hasonlítasz jobban.

Elsőként elmagyarázzuk Neked, hogyan múködnek ezek az állítások egy példával.

Íme egy állítás, amire már válaszolt egy gyerek:

\begin{tabular}{|c|l|l|l|l|l|c|}
\hline $\begin{array}{l}\text { Nagyon } \\
\text { igaz rám }\end{array}$ & $\begin{array}{l}\text { Kicsit } \\
\text { igaz rám }\end{array}$ & $\begin{array}{l}\text { Vannak olyan } \\
\text { gyerekek, akik } \\
\text { szeretnek játszani } \\
\text { az udvaron } \\
\text { szabadidejükben. }\end{array}$ & DE & $\begin{array}{l}\text { Más gyerekek } \\
\text { szeretnek } \\
\text { tévét nézni } \\
\text { szabad- } \\
\text { idejükben. }\end{array}$ & $\begin{array}{l}\text { Kicsit } \\
\text { igaz rám }\end{array}$ & $\begin{array}{l}\text { Nagyon } \\
\text { igaz rám }\end{array}$ \\
\cline { 5 - 7 } & $\square$ & & $\square$ & $\square$ \\
\hline
\end{tabular}

1. Mielőtt válaszolsz, kérlek olvasd el figyelmesen mind a kettő mondatot. Ebben a példában a két mondat: „Vannak gyerekek, akik szeretnek játszani az udvaron szabadidejükben.” és „Más gyerekek szeretnek tévét nézni szabadidejükben."

2. Döntsd el, hogy a bal oldali állításban (akik szeretnek játszani az udvaron), vagy a jobb oldali állításban (akik szeretnek tévét nézni) szereplő gyerekre hasonítasz jobban.

3. Csak azt a mondatot nézd, amelyik állítás gyerekeire jobban hasonlítasz.

4. Most azt döntsd el, hogy az a mondat, amit választottál nagyon igaz rád vagy kicsit igaz rád, és ha választottál, tegyél egy x-et a megfeleló kis négyzetbe.

\section{FIGYELEM!}

Csak egy kis négyzetbe tegyél x-et (abba, ami jobban igaz rád, amelyik jobban hasonlít rád), míg a másik kérdésre nem kell válaszolnod. 


\section{A következő kérdések rólad és az anyukádról szólnak!}

\begin{tabular}{|c|c|c|c|c|c|c|}
\hline $\begin{array}{l}\text { AN_1 } \\
\text { Nagyon } \\
\text { igaz rám }\end{array}$ & $\begin{array}{l}\text { Kicsit } \\
\text { igaz rám }\end{array}$ & \multirow{2}{*}{$\begin{array}{l}\text { Vannak olyan } \\
\text { gyerekek, akik } \\
\text { úgy érzik, hogy } \\
\text { könnyú } \\
\text { megbízniuk az } \\
\text { anyukájukban. }\end{array}$} & \multirow{2}{*}{$\mathrm{DE}$} & \multirow{2}{*}{$\begin{array}{l}\text { Más gyerekek } \\
\text { nem biztosak } \\
\text { benne, hogy } \\
\text { megbízhatnak } \\
\text { az } \\
\text { anyukájukban. }\end{array}$} & $\begin{array}{l}\text { Kicsit } \\
\text { igaz rám }\end{array}$ & $\begin{array}{l}\text { Nagyon } \\
\text { igaz rám }\end{array}$ \\
\hline & & & & & & \\
\hline $\begin{array}{l}\text { AN_2 } \\
\text { Nagyon } \\
\text { igaz rám }\end{array}$ & $\begin{array}{l}\text { Kicsit } \\
\text { igaz rám }\end{array}$ & \multirow{2}{*}{$\begin{array}{l}\text { Vannak olyan } \\
\text { gyerekek, akik } \\
\text { úgy érzik, hogy } \\
\text { az anyukájuk } \\
\text { sokszor beleszól } \\
\text { a dolgukba, ha } \\
\text { megpróbálnak } \\
\text { önállóan csinálni } \\
\text { valamit. }\end{array}$} & \multirow[b]{2}{*}{$\mathrm{DE}$} & \multirow{2}{*}{$\begin{array}{l}\text { Más gyerekek } \\
\text { úgy érzik, az } \\
\text { anyukájuk } \\
\text { hagyja, hogy } \\
\text { önállóan } \\
\text { végezzék a } \\
\text { dolgukat. }\end{array}$} & $\begin{array}{l}\text { Kicsit } \\
\text { igaz rám }\end{array}$ & $\begin{array}{l}\text { Nagyon } \\
\text { igaz rám }\end{array}$ \\
\hline & & & & & & \\
\hline \multirow[t]{2}{*}{$\begin{array}{l}\text { AN_3 } \\
\text { Nagyon } \\
\text { igaz rám }\end{array}$} & $\begin{array}{l}\text { Kicsit } \\
\text { igaz rám }\end{array}$ & \multirow{2}{*}{$\begin{array}{l}\text { Vannak olyan } \\
\text { gyerekek, akik } \\
\text { úgy érzik, hogy } \\
\text { számíthatnak az } \\
\text { anyukájukra, ha } \\
\text { segítségre lenne } \\
\text { szükségük. }\end{array}$} & \multirow[b]{2}{*}{$\mathrm{DE}$} & \multirow{2}{*}{$\begin{array}{l}\text { Más gyerekek } \\
\text { úgy érzik, nem } \\
\text { biztos, hogy } \\
\text { számíthatnak } \\
\text { az anyukájukra, } \\
\text { ha segítségre } \\
\text { lenne } \\
\text { szükségük. }\end{array}$} & $\begin{array}{l}\text { Kicsit } \\
\text { igaz rám }\end{array}$ & $\begin{array}{l}\text { Nagyon } \\
\text { igaz rám }\end{array}$ \\
\hline & & & & & & \\
\hline \multirow[t]{2}{*}{$\begin{array}{l}\text { AN_4 } \\
\text { Nagyon } \\
\text { igaz rám }\end{array}$} & $\begin{array}{l}\text { Kicsit } \\
\text { igaz rám }\end{array}$ & \multirow{2}{*}{$\begin{array}{l}\text { Vannak olyan } \\
\text { gyerekek, akik } \\
\text { úgy gondolják, } \\
\text { hogy az } \\
\text { anyukájuk elég } \\
\text { időt tölt velük. }\end{array}$} & \multirow{2}{*}{$\mathrm{DE}$} & \multirow{2}{*}{$\begin{array}{l}\text { Más gyerekek } \\
\text { úgy gondolják, } \\
\text { hogy az } \\
\text { anyukájuk nem } \\
\text { tölt elég időt } \\
\text { velük. }\end{array}$} & $\begin{array}{l}\text { Kicsit } \\
\text { igaz rám }\end{array}$ & $\begin{array}{l}\text { Nagyon } \\
\text { igaz rám }\end{array}$ \\
\hline & & & & & & \\
\hline \multirow[t]{2}{*}{$\begin{array}{l}\text { AN_5 } \\
\text { Nagyon } \\
\text { igaz rám }\end{array}$} & $\begin{array}{l}\text { Kicsit } \\
\text { igaz rám }\end{array}$ & \multirow{2}{*}{$\begin{array}{l}\text { Vannak olyan } \\
\text { gyerekek, akik } \\
\text { nem szívesen } \\
\text { beszélnek az } \\
\text { anyukájukkal } \\
\text { arról, hogy mit } \\
\text { gondolnak, és } \\
\text { mit éreznek. }\end{array}$} & \multirow[b]{2}{*}{ DE } & \multirow{2}{*}{$\begin{array}{l}\text { Más gyerekek } \\
\text { szívesen osztják } \\
\text { meg } \\
\text { gondolataikat } \\
\text { és érzéseiket az } \\
\text { anyukájukkal. }\end{array}$} & $\begin{array}{l}\text { Kicsit } \\
\text { igaz rám }\end{array}$ & $\begin{array}{l}\text { Nagyon } \\
\text { igaz rám }\end{array}$ \\
\hline & & & & & & \\
\hline
\end{tabular}




\begin{tabular}{|c|c|c|c|c|c|c|}
\hline $\begin{array}{l}\text { AN_6 } \\
\text { Nagyon } \\
\text { igaz rám }\end{array}$ & $\begin{array}{l}\text { Kicsit } \\
\text { igaz rám }\end{array}$ & \multirow{2}{*}{$\begin{array}{l}\text { Vannak olyan } \\
\text { gyerekek, akik } \\
\text { úgy érzik, hogy } \\
\text { nem sok } \\
\text { mindenben van } \\
\text { szükségük az } \\
\text { anyukájukra. }\end{array}$} & \multirow[b]{2}{*}{$\mathrm{DE}$} & \multirow{2}{*}{$\begin{array}{l}\text { Más gyerekek } \\
\text { úgy érzik, sok } \\
\text { mindenben van } \\
\text { szükségük az } \\
\text { anyukájukra. }\end{array}$} & $\begin{array}{l}\text { Kicsit } \\
\text { igaz rám }\end{array}$ & $\begin{array}{l}\text { Nagyon } \\
\text { igaz rám }\end{array}$ \\
\hline & & & & & & \\
\hline $\begin{array}{l}\text { AN_7 } \\
\text { Nagyon } \\
\text { igaz rám }\end{array}$ & $\begin{array}{l}\text { Kicsit } \\
\text { igaz rám }\end{array}$ & $\begin{array}{l}\text { Vannak olyan } \\
\text { gyerekek, akik }\end{array}$ & & $\begin{array}{l}\text { Más gyerekek } \\
\text { úgy gondolják, }\end{array}$ & $\begin{array}{l}\text { Kicsit } \\
\text { igaz rám }\end{array}$ & $\begin{array}{l}\text { Nagyon } \\
\text { igaz rám }\end{array}$ \\
\hline & & $\begin{array}{l}\text { hogy jó érzés } \\
\text { lenne, ha } \\
\text { érzelmileg } \\
\text { közelebb } \\
\text { tudnának } \\
\text { kerülni az } \\
\text { anyukájukhoz. }\end{array}$ & $\mathrm{DE}$ & $\begin{array}{l}\text { éppen elég } \\
\text { közel állnak az } \\
\text { anyukájukhoz. }\end{array}$ & & \\
\hline $\begin{array}{l}\text { AN_8 } \\
\text { Nagyon } \\
\text { igaz rám }\end{array}$ & $\begin{array}{l}\text { Kicsit } \\
\text { igaz rám }\end{array}$ & $\begin{array}{l}\text { Vannak olyan } \\
\text { gyerekek, akik }\end{array}$ & & $\begin{array}{l}\text { Más gyerekek } \\
\text { teljesen }\end{array}$ & $\begin{array}{l}\text { Kicsit } \\
\text { igaz rám }\end{array}$ & $\begin{array}{l}\text { Nagyon } \\
\text { igaz rám }\end{array}$ \\
\hline & & $\begin{array}{l}\text { hogy az } \\
\text { anyukájuk nem } \\
\text { szereti őket } \\
\text { igazán. }\end{array}$ & DE & $\begin{array}{l}\text { hogy az } \\
\text { anyukájuk } \\
\text { igazán szereti } \\
\text { őket. }\end{array}$ & & \\
\hline $\begin{array}{l}\text { AN_9 } \\
\text { Nagyon } \\
\text { igaz rám }\end{array}$ & $\begin{array}{l}\text { Kicsit } \\
\text { igaz rám }\end{array}$ & $\begin{array}{l}\text { Vannak olyan } \\
\text { gyerekek, akik } \\
\text { úgy érzik, hogy }\end{array}$ & $\mathrm{DE}$ & $\begin{array}{l}\text { Más gyerekek } \\
\text { úgy érzik, hogy } \\
\text { az anyukájuk }\end{array}$ & $\begin{array}{l}\text { Kicsit } \\
\text { igaz rám }\end{array}$ & $\begin{array}{l}\text { Nagyon } \\
\text { igaz rám }\end{array}$ \\
\hline & & megérti őket. & & $\begin{array}{l}\text { nem rgazan ertı } \\
\text { meg őket. }\end{array}$ & & \\
\hline $\begin{array}{l}\text { AN_10 } \\
\text { Nagyon } \\
\text { igaz rám }\end{array}$ & $\begin{array}{l}\text { Kicsit } \\
\text { igaz rám }\end{array}$ & $\begin{array}{l}\text { Vannak olyan } \\
\text { gyerekek, akik } \\
\text { biztosak benne, }\end{array}$ & & $\begin{array}{l}\text { Más gyerekek } \\
\text { néha el tudják } \\
\text { képzelni, hogy }\end{array}$ & $\begin{array}{l}\text { Kicsit } \\
\text { igaz rám }\end{array}$ & $\begin{array}{l}\text { Nagyon } \\
\text { igaz rám }\end{array}$ \\
\hline & & $\begin{array}{l}\text { anyukájuk } \\
\text { sosem hagyná el } \\
\text { őket. }\end{array}$ & & $\begin{array}{l}\text { esetleg elhagyja } \\
\text { óket. }\end{array}$ & & \\
\hline
\end{tabular}




\begin{tabular}{|c|c|c|c|c|c|c|}
\hline $\begin{array}{l}\text { AN_11 } \\
\text { Nagyon } \\
\text { igaz rám }\end{array}$ & $\begin{array}{l}\text { Kicsit } \\
\text { igaz rám }\end{array}$ & \multirow{2}{*}{$\begin{array}{l}\text { Vannak olyan } \\
\text { gyerekek, akik } \\
\text { tartanak attól, } \\
\text { hogy az } \\
\text { anyukájuk nem } \\
\text { lesz mindig } \\
\text { elérhetó } \\
\text { számukra, ha } \\
\text { segítségre } \\
\text { szorulnak. }\end{array}$} & \multirow[b]{2}{*}{ DE } & \multirow{2}{*}{$\begin{array}{l}\text { Más gyerekek } \\
\text { teljesen } \\
\text { biztosak abban, } \\
\text { hogy az } \\
\text { anyukájuk } \\
\text { mindig elérhetó } \\
\text { lesz számukra, } \\
\text { ha segítségére } \\
\text { szorulnak. }\end{array}$} & $\begin{array}{l}\text { Kicsit } \\
\text { igaz rám }\end{array}$ & $\begin{array}{l}\text { Nagyon } \\
\text { igaz rám }\end{array}$ \\
\hline & & & & & & \\
\hline \multirow[t]{2}{*}{$\begin{array}{l}\text { AN_12 } \\
\text { Nagyon } \\
\text { igaz rám }\end{array}$} & $\begin{array}{l}\text { Kicsit } \\
\text { igaz rám }\end{array}$ & \multirow{2}{*}{$\begin{array}{l}\text { Vannak olyan } \\
\text { gyerekek, akik } \\
\text { úgy gondolják, } \\
\text { hogy az } \\
\text { anyukájuk nem } \\
\text { mindig kellő } \\
\text { figyelemmel } \\
\text { hallgatja meg } \\
\text { őket. }\end{array}$} & \multirow[b]{2}{*}{$\mathrm{DE}$} & \multirow{2}{*}{$\begin{array}{l}\text { Más gyerekek } \\
\text { úgy gondolják, } \\
\text { hogy az } \\
\text { anyukájuk } \\
\text { mindig } \\
\text { figyelmesen } \\
\text { meghallgatja } \\
\text { óket. }\end{array}$} & $\begin{array}{l}\text { Kicsit } \\
\text { igaz rám }\end{array}$ & $\begin{array}{l}\text { Nagyon } \\
\text { igaz rám }\end{array}$ \\
\hline & & & & & & \\
\hline \multirow[t]{2}{*}{$\begin{array}{l}\text { AN_13 } \\
\text { Nagyon } \\
\text { igaz rám }\end{array}$} & $\begin{array}{l}\text { Kicsit } \\
\text { igaz rám }\end{array}$ & \multirow{2}{*}{$\begin{array}{l}\text { Vannak olyan } \\
\text { gyerekek, } \\
\text { akik az } \\
\text { anyukájukhoz } \\
\text { fordulnak, ha } \\
\text { valami bántja } \\
\text { vagy felzaklatja } \\
\text { őket. }\end{array}$} & \multirow[b]{2}{*}{$\mathrm{DE}$} & \multirow{2}{*}{$\begin{array}{l}\text { Más gyerekek } \\
\text { nem fordulnak } \\
\text { az } \\
\text { anyukájukhoz, } \\
\text { ha valami } \\
\text { bántja vagy } \\
\text { felzaklatja őket. }\end{array}$} & $\begin{array}{l}\text { Kicsit } \\
\text { igaz rám }\end{array}$ & $\begin{array}{l}\text { Nagyon } \\
\text { igaz rám }\end{array}$ \\
\hline & & & & & & \\
\hline \multirow[t]{2}{*}{$\begin{array}{l}\text { AN_14 } \\
\text { Nagyon } \\
\text { igaz rám }\end{array}$} & $\begin{array}{l}\text { Kicsit } \\
\text { igaz rám }\end{array}$ & \multirow{2}{*}{$\begin{array}{l}\text { Vannak olyan } \\
\text { gyerekek, akik } \\
\text { szeretnék, ha az } \\
\text { anyukájuk } \\
\text { többet segítene } \\
\text { nekik a } \\
\text { problémáik } \\
\text { megoldásában. }\end{array}$} & \multirow[t]{2}{*}{$\mathrm{DE}$} & \multirow{2}{*}{$\begin{array}{l}\text { Más gyerekek } \\
\text { úgy gondolják, } \\
\text { az anyukájuk } \\
\text { éppen eleget } \\
\text { segít nekik a } \\
\text { problémáik } \\
\text { megoldásában. }\end{array}$} & $\begin{array}{l}\text { Kicsit } \\
\text { igaz rám }\end{array}$ & $\begin{array}{l}\text { Nagyon } \\
\text { igaz rám }\end{array}$ \\
\hline & & & & & & \\
\hline \multirow[t]{2}{*}{$\begin{array}{l}\text { AN_15 } \\
\text { Nagyon } \\
\text { igaz rám }\end{array}$} & $\begin{array}{l}\text { Kicsit } \\
\text { igaz rám }\end{array}$ & \multirow{2}{*}{$\begin{array}{l}\text { Vannak olyan } \\
\text { gyerekek, akik } \\
\text { jobban érzik } \\
\text { magukat, ha az } \\
\text { anyukájuk a } \\
\text { közelben van. }\end{array}$} & \multirow{2}{*}{$\mathrm{DE}$} & \multirow{2}{*}{$\begin{array}{l}\text { Más gyerekek } \\
\text { nem érzik } \\
\text { magukat } \\
\text { jobban, ha az } \\
\text { anyukájuk a } \\
\text { közelben van. }\end{array}$} & $\begin{array}{l}\text { Kicsit } \\
\text { igaz rám }\end{array}$ & $\begin{array}{l}\text { Nagyon } \\
\text { igaz rám }\end{array}$ \\
\hline & & & & & & \\
\hline
\end{tabular}




\section{A következő kérdések rólad és az apukádról szólnak!}

\begin{tabular}{|c|c|c|c|c|c|c|}
\hline $\begin{array}{l}\text { AP_1 } \\
\text { Nagyon } \\
\text { igaz rám }\end{array}$ & $\begin{array}{l}\text { Kicsit } \\
\text { igaz rám }\end{array}$ & \multirow{2}{*}{$\begin{array}{l}\text { Vannak olyan } \\
\text { gyerekek, akik } \\
\text { úgy érzik, } \\
\text { hogy könnyú } \\
\text { megbízniuk az } \\
\text { apukájukban. }\end{array}$} & \multirow{2}{*}{$\mathrm{DE}$} & \multirow{2}{*}{$\begin{array}{l}\text { Más gyerekek } \\
\text { nem biztosak } \\
\text { benne, hogy } \\
\text { megbízhatnak } \\
\text { az } \\
\text { apukájukban. }\end{array}$} & $\begin{array}{l}\text { Kicsit } \\
\text { igaz rám }\end{array}$ & $\begin{array}{l}\text { Nagyon } \\
\text { igaz rám }\end{array}$ \\
\hline & & & & & & \\
\hline \multirow[t]{2}{*}{$\begin{array}{l}\mathrm{AP} \_2 \\
\text { Nagyon } \\
\text { igaz rám }\end{array}$} & $\begin{array}{l}\text { Kicsit } \\
\text { igaz rám }\end{array}$ & \multirow{2}{*}{$\begin{array}{l}\text { Vannak olyan } \\
\text { gyerekek, akik } \\
\text { úgy érzik, } \\
\text { hogy az } \\
\text { apukájuk } \\
\text { sokszor } \\
\text { beleszól a } \\
\text { dolgukba, ha } \\
\text { megpróbálnak } \\
\text { önállóan } \\
\text { csinálni } \\
\text { valamit. }\end{array}$} & \multirow[b]{2}{*}{$\mathrm{DE}$} & \multirow{2}{*}{$\begin{array}{l}\text { Más gyerekek } \\
\text { úgy érzik, az } \\
\text { apukájuk } \\
\text { hagyja, hogy } \\
\text { önállóan } \\
\text { végezzék a } \\
\text { dolgukat. }\end{array}$} & $\begin{array}{l}\text { Kicsit } \\
\text { igaz rám }\end{array}$ & $\begin{array}{l}\text { Nagyon } \\
\text { igaz rám }\end{array}$ \\
\hline & & & & & & \\
\hline \multirow[t]{2}{*}{$\begin{array}{l}\text { AP_3 } \\
\text { Nagyon } \\
\text { igaz rám }\end{array}$} & $\begin{array}{l}\text { Kicsit } \\
\text { igaz rám }\end{array}$ & \multirow{2}{*}{$\begin{array}{l}\text { Vannak olyan } \\
\text { gyerekek, akik } \\
\text { úgy érzik, } \\
\text { hogy } \\
\text { számíthatnak } \\
\text { az apukájukra, } \\
\text { ha segítségre } \\
\text { lenne } \\
\text { szükségük. }\end{array}$} & \multirow[b]{2}{*}{$\mathrm{DE}$} & \multirow{2}{*}{$\begin{array}{l}\text { Más gyerekek } \\
\text { úgy érzik, nem } \\
\text { biztos, hogy } \\
\text { számíthatnak } \\
\text { az apukájukra, } \\
\text { ha segítségre } \\
\text { lenne } \\
\text { szükségük. }\end{array}$} & $\begin{array}{l}\text { Kicsit } \\
\text { igaz rám }\end{array}$ & $\begin{array}{l}\text { Nagyon } \\
\text { igaz rám }\end{array}$ \\
\hline & & & & & & \\
\hline \multirow[t]{2}{*}{$\begin{array}{l}\mathrm{AP}_{-} 4 \\
\text { Nagyon } \\
\text { igaz rám }\end{array}$} & $\begin{array}{l}\text { Kicsit } \\
\text { igaz rám }\end{array}$ & \multirow{2}{*}{$\begin{array}{l}\text { Vannak olyan } \\
\text { gyerekek, akik } \\
\text { úgy gondolják, } \\
\text { hogy az } \\
\text { apukájuk elég } \\
\text { időt tölt velük. }\end{array}$} & \multirow{2}{*}{$\mathrm{DE}$} & \multirow{2}{*}{$\begin{array}{l}\text { Más gyerekek } \\
\text { úgy gondolják, } \\
\text { hogy az } \\
\text { apukájuk nem } \\
\text { tölt elég időt } \\
\text { velük. }\end{array}$} & $\begin{array}{l}\text { Kicsit } \\
\text { igaz rám }\end{array}$ & $\begin{array}{l}\text { Nagyon } \\
\text { igaz rám }\end{array}$ \\
\hline & & & & & & \\
\hline \multirow[t]{2}{*}{$\begin{array}{l}\text { AP_5 } \\
\text { Nagyon } \\
\text { igaz rám }\end{array}$} & $\begin{array}{l}\text { Kicsit } \\
\text { igaz rám }\end{array}$ & \multirow{2}{*}{$\begin{array}{l}\text { Vannak olyan } \\
\text { gyerekek, akik } \\
\text { nem szívesen } \\
\text { beszélnek az } \\
\text { apukájukkal } \\
\text { arról, hogy mit } \\
\text { gondolnak, és } \\
\text { mit éreznek. }\end{array}$} & \multirow[b]{2}{*}{ DE } & \multirow{2}{*}{$\begin{array}{l}\text { Más gyerekek } \\
\text { szívesen } \\
\text { osztják meg } \\
\text { gondolataikat } \\
\text { és érzéseiket az } \\
\text { apukájukkal. }\end{array}$} & $\begin{array}{l}\text { Kicsit } \\
\text { igaz rám }\end{array}$ & $\begin{array}{l}\text { Nagyon } \\
\text { igaz rám }\end{array}$ \\
\hline & & & & & & \\
\hline
\end{tabular}




\begin{tabular}{|c|c|c|c|c|c|c|}
\hline $\begin{array}{l}\text { AP_6 } \\
\text { Nagyon } \\
\text { igaz rám }\end{array}$ & $\begin{array}{l}\text { Kicsit } \\
\text { igaz rám }\end{array}$ & \multirow{2}{*}{$\begin{array}{l}\text { Vannak olyan } \\
\text { gyerekek, akik } \\
\text { úgy érzik, } \\
\text { hogy nem sok } \\
\text { mindenben } \\
\text { van szükségük } \\
\text { az apukájukra. }\end{array}$} & \multirow[b]{2}{*}{ DE } & \multirow{2}{*}{$\begin{array}{l}\text { Más gyerekek } \\
\text { úgy érzik, sok } \\
\text { mindenben van } \\
\text { szükségük az } \\
\text { apukájukra. }\end{array}$} & \multirow[t]{2}{*}{$\begin{array}{l}\text { Kicsit } \\
\text { igaz rám }\end{array}$} & \multirow[t]{2}{*}{$\begin{array}{l}\text { Nagyon } \\
\text { igaz rám }\end{array}$} \\
\hline & & & & & & \\
\hline $\begin{array}{l}\mathrm{AP} \text { _7 } \\
\text { Nagyon } \\
\text { igaz rám }\end{array}$ & $\begin{array}{l}\text { Kicsit } \\
\text { igaz rám }\end{array}$ & \multirow{2}{*}{$\begin{array}{l}\text { Vannak olyan } \\
\text { gyerekek, akik } \\
\text { úgy gondolják, } \\
\text { hogy jó érzés } \\
\text { lenne, ha } \\
\text { érzelmileg } \\
\text { közelebb } \\
\text { tudnának } \\
\text { kerülni az } \\
\text { apukájukhoz. }\end{array}$} & \multirow[b]{2}{*}{$\mathrm{DE}$} & \multirow{2}{*}{$\begin{array}{l}\text { Más gyerekek } \\
\text { úgy gondolják, } \\
\text { hogy } \\
\text { érzelmileg } \\
\text { éppen elég } \\
\text { közel állnak az } \\
\text { apukájukhoz. }\end{array}$} & $\begin{array}{l}\text { Kicsit } \\
\text { igaz rám }\end{array}$ & $\begin{array}{l}\text { Nagyon } \\
\text { igaz rám }\end{array}$ \\
\hline & & & & & & \\
\hline \multirow[t]{2}{*}{$\begin{array}{l}\text { AP_8 } \\
\text { Nagyon } \\
\text { igaz rám }\end{array}$} & $\begin{array}{l}\text { Kicsit } \\
\text { igaz rám }\end{array}$ & \multirow{2}{*}{$\begin{array}{l}\text { Vannak olyan } \\
\text { gyerekek, akik } \\
\text { tartanak attól, } \\
\text { hogy az } \\
\text { apukájuk nem } \\
\text { szereti óket } \\
\text { igazán. }\end{array}$} & \multirow{2}{*}{$\mathrm{DE}$} & \multirow{2}{*}{$\begin{array}{l}\text { Más gyerekek } \\
\text { teljesen } \\
\text { biztosak abban, } \\
\text { hogy az } \\
\text { apukájuk } \\
\text { igazán szereti } \\
\text { őket. }\end{array}$} & $\begin{array}{l}\text { Kicsit } \\
\text { igaz rám }\end{array}$ & $\begin{array}{l}\text { Nagyon } \\
\text { igaz rám }\end{array}$ \\
\hline & & & & & & \\
\hline \multirow[t]{2}{*}{$\begin{array}{l}\text { AP_9 } \\
\text { Nagyon } \\
\text { igaz rám }\end{array}$} & $\begin{array}{l}\text { Kicsit } \\
\text { igaz rám }\end{array}$ & \multirow{2}{*}{$\begin{array}{l}\text { Vannak olyan } \\
\text { gyerekek, akik } \\
\text { úgy érzik, } \\
\text { hogy az } \\
\text { apukájuk } \\
\text { megérti óket. }\end{array}$} & \multirow{2}{*}{$\mathrm{DE}$} & \multirow{2}{*}{$\begin{array}{l}\text { Más gyerekek } \\
\text { úgy érzik, hogy } \\
\text { az apukájuk } \\
\text { nem igazán érti } \\
\text { meg óket. }\end{array}$} & $\begin{array}{l}\text { Kicsit } \\
\text { igaz rám }\end{array}$ & $\begin{array}{l}\text { Nagyon } \\
\text { igaz rám }\end{array}$ \\
\hline & & & & & & \\
\hline \multirow[t]{2}{*}{$\begin{array}{l}\text { AP_10 } \\
\text { Nagyon } \\
\text { igaz rám }\end{array}$} & $\begin{array}{l}\text { Kicsit } \\
\text { igaz rám }\end{array}$ & \multirow{2}{*}{$\begin{array}{l}\text { Vannak olyan } \\
\text { gyerekek, akik } \\
\text { biztosak benne, } \\
\text { hogy az } \\
\text { apukájuk } \\
\text { sosem hagyná } \\
\text { el őket. }\end{array}$} & \multirow[b]{2}{*}{ DE } & \multirow{2}{*}{$\begin{array}{l}\text { Más gyerekek } \\
\text { néha el tudják } \\
\text { képzelni, hogy } \\
\text { az apukájuk } \\
\text { esetleg } \\
\text { elhagyja óket. }\end{array}$} & $\begin{array}{l}\text { Kicsit } \\
\text { igaz rám }\end{array}$ & $\begin{array}{l}\text { Nagyon } \\
\text { igaz rám }\end{array}$ \\
\hline & & & & & & \\
\hline
\end{tabular}




\begin{tabular}{|c|c|c|c|c|c|c|}
\hline $\begin{array}{l}\text { AP_11 } \\
\text { Nagyon } \\
\text { igaz rám }\end{array}$ & $\begin{array}{l}\text { Kicsit } \\
\text { igaz rám }\end{array}$ & \multirow{2}{*}{$\begin{array}{l}\text { Vannak olyan } \\
\text { gyerekek, akik } \\
\text { tartanak attól, } \\
\text { hogy az } \\
\text { apukájuk nem } \\
\text { lesz mindig } \\
\text { elérhetó } \\
\text { számukra, ha } \\
\text { segítségre } \\
\text { szorulnak. }\end{array}$} & \multirow[b]{2}{*}{$\mathrm{DE}$} & \multirow{2}{*}{$\begin{array}{l}\text { Más gyerekek } \\
\text { teljesen } \\
\text { biztosak abban, } \\
\text { hogy az } \\
\text { apukájuk } \\
\text { mindig } \\
\text { elérhetó lesz } \\
\text { számukra, ha } \\
\text { segítségére } \\
\text { szorulnak. }\end{array}$} & $\begin{array}{l}\text { Kicsit } \\
\text { igaz rám }\end{array}$ & $\begin{array}{l}\text { Nagyon } \\
\text { igaz rám }\end{array}$ \\
\hline & & & & & & \\
\hline $\begin{array}{l}\text { AP_12 } \\
\text { Nagyon } \\
\text { igaz rám }\end{array}$ & $\begin{array}{l}\text { Kicsit } \\
\text { igaz rám }\end{array}$ & $\begin{array}{l}\text { Vannak olyan } \\
\text { gyerekek, akik }\end{array}$ & & $\begin{array}{l}\text { Más gyerekek } \\
\text { úgy gondolják, }\end{array}$ & $\begin{array}{l}\text { Kicsit } \\
\text { igaz rám }\end{array}$ & $\begin{array}{l}\text { Nagyon } \\
\text { igaz rám }\end{array}$ \\
\hline & & $\begin{array}{l}\text { hogy az } \\
\text { apukájuk nem } \\
\text { mindig kellő } \\
\text { figyelemmel } \\
\text { hallgatja meg } \\
\text { óket. }\end{array}$ & $\mathrm{DE}$ & $\begin{array}{l}\text { apukájuk } \\
\text { mindig } \\
\text { figyelmesen } \\
\text { meghallgatja } \\
\text { őket. }\end{array}$ & & \\
\hline $\begin{array}{l}\text { AP_13 } \\
\text { Nagyon } \\
\text { igaz rám }\end{array}$ & $\begin{array}{l}\text { Kicsit } \\
\text { igaz rám }\end{array}$ & $\begin{array}{l}\text { Vannak olyan } \\
\text { gyerekek, akik }\end{array}$ & & $\begin{array}{l}\text { Más gyerekek } \\
\text { nem fordulnak }\end{array}$ & $\begin{array}{l}\text { Kicsit } \\
\text { igaz rám }\end{array}$ & $\begin{array}{l}\text { Nagyon } \\
\text { igaz rám }\end{array}$ \\
\hline & & $\begin{array}{l}\text { az apukajuk- } \\
\text { hoz fordulnak, } \\
\text { ha valami } \\
\text { bántja vagy } \\
\text { felzaklatja őket. }\end{array}$ & $\mathrm{DE}$ & $\begin{array}{l}\text { az } \\
\text { apukájukhoz, } \\
\text { ha valami } \\
\text { bántja vagy } \\
\text { felzaklatja őket. }\end{array}$ & & \\
\hline $\begin{array}{l}\text { AP_14 } \\
\text { Nagyon } \\
\text { igaz rám }\end{array}$ & $\begin{array}{l}\text { Kicsit } \\
\text { igaz rám }\end{array}$ & $\begin{array}{l}\text { Vannak olyan } \\
\text { gyerekek, akik }\end{array}$ & & $\begin{array}{l}\text { Más gyerekek } \\
\text { úgy gondolják, }\end{array}$ & $\begin{array}{l}\text { Kicsit } \\
\text { igaz rám }\end{array}$ & $\begin{array}{l}\text { Nagyon } \\
\text { igaz rám }\end{array}$ \\
\hline & & $\begin{array}{l}\text { az apukájuk } \\
\text { többet segítene } \\
\text { nekik a } \\
\text { problémáik } \\
\text { megoldásában. }\end{array}$ & $\mathrm{DE}$ & $\begin{array}{l}\text { éppen eleget } \\
\text { segít nekik a } \\
\text { problémáik } \\
\text { megoldásában. }\end{array}$ & & \\
\hline $\begin{array}{l}\text { AP_15 } \\
\text { Nagyon } \\
\text { igaz rám }\end{array}$ & $\begin{array}{l}\text { Kicsit } \\
\text { igaz rám }\end{array}$ & $\begin{array}{l}\text { Vannak olyan } \\
\text { gyerekek, akik }\end{array}$ & & $\begin{array}{l}\text { Más gyerekek } \\
\text { nem érzik }\end{array}$ & $\begin{array}{l}\text { Kicsit } \\
\text { igaz rám }\end{array}$ & $\begin{array}{l}\text { Nagyon } \\
\text { igaz rám }\end{array}$ \\
\hline & & $\begin{array}{l}\text { magukat, ha az } \\
\text { apukájuk a } \\
\text { közelben van. }\end{array}$ & & $\begin{array}{l}\text { jobban, ha az } \\
\text { apukájuk a } \\
\text { közelben van. }\end{array}$ & & \\
\hline
\end{tabular}

* The items have been constructed and published in English by Kerns et al. (2001).

The Hungarian version is translated and adapted by: Barcsi, B., Hollódy, K., Péley, B., Dorn, K., Kerns, K. A., Rózsa, S., Török, I. A., \& Kállai, J. (2017). Journal of Mental Health \& Psychosomatics. 


\section{Biztonság, bizalom és elérhetóség: A Kerns-féle Biztonság Skála pszichometriai jellemzői magyar populációban}

\section{BARCSI BEATRIX - HOLLÓDY KATALIN - PÉLEY BERNADETTE - DORN KRISZTINA - KERNS, KATHRYN A. - RÓZSA SÁNDOR - TÖRÖK IMRE A. - KÁLLAI JÁNOS}

Háttér: A tanulmány az Egyesült Állomokban és Európában egyaránt széles körben elterjedt Kerns-féle Biztonság Skála (KSS) hazai vizsgálatával kapcsolatos tapasztalatokat mutatja be. A kérdőív a gyermek családtagokkal kapcsolatos személyes érzéseit, apjával és anyjával kapcsolatos biztoság élményeit méri fel. Cél: Elemezzük a kérdőív faktorstruktúráját, a Gyermekdepresszió Kérdőív segítségével ellenőrizzük a validitását, továbbá hazai populációt vizsgálva leírjuk a skálák jellegzetességeit, valamint ellenórizzük a KSS klinikai praxisban és az iskolapszichológiai ellátásban való alkalmazhatóságát alsó, felső és középiskolás gyermekeknél. Módszer: A vizsgálatban 323 tanuló vett részt (137 fiú és 186 leány, életkor 10-18 év között). A résztvevők a KSS és a Gyermekdepresszió Skálát töltöttek ki. Eredmények: A Kerns-féle Biztonság Skála tételei faktoranalízisének eredménye szerint a kérdőív három alskálára bontható: ezek a szülők iránt érzett bizalom, a szülők szükség esetén való elérhetősége és az autonómia kezdeményezések támogatása. Az anyák alskála értékei magasabbak, mint az apáké (Bizalom: $t=7,1 ; p<0,001$; Elérhetőség $t=8,9 ; p<0,001$; Autonómia támogatása $t=3,2 ; p<0,01)$. Következtetés: Az eredmények a KSS háromfaktoros modelljét támasztják alá, továbbá rámutatnak arra, hogy a kérdőív megbízhatóan használható a klinikai praxisban és az iskolapszichológiai ellátásban egyaránt.

Kulcsszavak: kötődés, autonómia támogatása, depresszió, preadoleszcens, észlelt biztonság 